(C) 2021, The Authors. Published by Elsevier Inc. and Fass Inc. on behalf of the American Dairy Science Association ${ }^{\circledR}$. This is an open access article under the CC BY-NC-ND license (http://creativecommons.org/licenses/by-nc-nd/4.0/).

\title{
Application of udder surface temperature by infrared thermography for diagnosis of subclinical mastitis in Holstein cows located in tropical highlands
}

\author{
Juan Velasco-Bolaños, ${ }^{1,2 *}$ Cristian C. Ceballes-Serrano, ${ }^{3}$ Daniel Velásquez-Mejía, ${ }^{1}$ Juan Carlos Riaño-Rojas, ${ }^{3}$ \\ Carlos E. Giraldo, ${ }^{4}$ Jorge U. Carmona, ${ }^{4}$ and Alejandro Ceballos-Márquez ${ }^{1,2}$ \\ ${ }^{1}$ Grupo de Investigación en Calidad de Leche y Epidemiología Veterinaria (CLEV), Departamento de Producción Agropecuaria, \\ Universidad de Caldas, Calle 65 No 26-10, 170004 Manizales, Colombia \\ ${ }^{2}$ Grupo de Investigación en Biología de la Producción Pecuaria, Departamento de Producción Agropecuaria, Universidad de Caldas, \\ Calle 65 No 26-10, 170004 Manizales, Colombia \\ ${ }^{3}$ Computational Applications Group, Departamento de Matemática y Estadística, Universidad Nacional de Colombia, Carrera 27 No 64-60, \\ 170004 Manizales, Colombia \\ ${ }^{4}$ Grupo de Investigación Terapia Regenerativa, Departamento de Salud Animal, Universidad de Caldas, Calle 65 No 26-10, 170004 Manizales, \\ Colombia
}

\section{ABSTRACT}

Several reports have indicated that udder surface temperature (UST) can be a useful indicator of subclinical mastitis (SCM). The objective was to evaluate UST by infrared thermography (IRT) as a diagnostic tool for SCM and intramammary infection (IMI), and to assess the influence of environmental conditions in the potential diagnosis of this disease in dairy cows located at high-altitude tropical regions. A total of 105 cows (397 quarters) from 3 dairy farms with mechanical and manual milking methods were enrolled in the study. Subclinical mastitis was diagnosed when quarter samples had a somatic cell count $\left(\right.$ SCC) $\geq 200 \times 10^{3}$ cells/mL, microbial growth (MG) was defined when a major pathogen ( $\geq 1 \mathrm{cfu} /$ plate) or Corynebacterium spp. ( $\geq 10 \mathrm{cfu} /$ plate) was isolated, and IMI was defined as the presence of MG and SCC $\geq 100 \times 10^{3}$ cells/ $\mathrm{mL}$. Infrared images were taken with a thermal camera placed $1 \mathrm{~m}$ away from the udder, and shots of the rear and left and right lateral view were made during the morning milking, before any manipulation of the udder and employing dark cardboard on the contralateral side to avoid artifacts in the background. A multilevel mixed effects linear regression model clustered within cows and herd was performed to evaluate the associations with UST. Clinical performance was evaluated using the Youden index to establish the optimum UST thresholds, which were set at $32.6^{\circ} \mathrm{C}$ for any case definition when milking was by hand, at $33.7^{\circ} \mathrm{C}$ for $\mathrm{MG}$, and at $34^{\circ} \mathrm{C}$ for $\mathrm{SCM}$ and IMI in machine-milked

Received November 10, 2020

Accepted April 20, 2021.

*Corresponding author: juan.velasco@ucaldas.edu.co quarters. Sensitivity (Se), specificity (Sp), area under curve (AUC), and positive likelihood ratio ( $+\mathrm{LR})$ were also assessed. Test agreement was assessed by kappa coefficient $(\kappa)$. The UST of healthy quarters ranged between $(95 \% \mathrm{CI}) 32.4$ and $32.6^{\circ} \mathrm{C}$, lower than SCM quarters $(\mathrm{n}=88)$ at $32.9^{\circ} \mathrm{C}\left(95 \% \mathrm{CI}: 32.7-33.1^{\circ} \mathrm{C}\right), \mathrm{MG}$ quarters $(\mathrm{n}=56)$ at $33.5^{\circ} \mathrm{C}\left(95 \% \mathrm{CI}: 33.3-33.7^{\circ} \mathrm{C}\right)$, and IMI quarters $(\mathrm{n}=50)$ at $33.5^{\circ} \mathrm{C}\left(95 \% \mathrm{CI}: 33.2-33.7^{\circ} \mathrm{C}\right)$. The UST was also related to the milking method: higher temperatures were observed for hand milking (n =90) compared with machine milking $(\mathrm{n}=185)$. No relation between environmental conditions such as wind speed, atmospheric temperature, relative humidity, and temperature-humidity index and UST were observed during this study. For hand milking, the optimal UST threshold was $32.6^{\circ} \mathrm{C}$; for $\mathrm{SCM}, \mathrm{Se}=0.53, \mathrm{Sp}=0.89$, $\mathrm{AUC}=0.71, \kappa=0.4 ;$ for $\mathrm{MG}, \mathrm{Se}=0.83, \mathrm{Sp}=0.93$, $\mathrm{AUC}=0.88, \kappa=0.77$; and for IMI, Se $=0.82, \mathrm{Sp}$ $=0.92, \mathrm{AUC}=0.87, \kappa=0.74$. The machine milking threshold for SCM resulted in $\mathrm{Se}=0.42, \mathrm{Sp}=0.97$, $\mathrm{AUC}=0.70, \kappa=0.47$; for $\mathrm{MG}, \mathrm{Se}=0.82, \mathrm{Sp}=0.89$, $\mathrm{AUC}=0.85, \kappa=0.60 ;$ and for IMI, Se $=0.82, \mathrm{Sp}=$ $0.98, \mathrm{AUC}=0.90, \kappa=0.79$. These findings suggest that UST determined by IRT is higher in machinemilked cows and in quarters with MG and IMI than in healthy quarters; therefore, UST by IRT is a reliable, clinically useful method for MG and IMI diagnosis.

Key words: dairy cow, intramammary infection, somatic cell count, thermal camera

\section{INTRODUCTION}

Mastitis is one of the most common disease of dairy cattle worldwide. It affects milk yield and quality, which leads to a lower economic return and affects farm sustainability. Many etiological agents may cause mastitis, 
such as Staphylococcus aureus, Streptococcus agalactiae, and Streptococcus uberis, among others (Gonçalves et al., 2018). In response to udder infection, a neutrophilic migration occurs from the blood to the milk, with a final increase of SCC in the milk (Harmon, 1994).

Mastitis may be classified as subclinical (SCM) or clinical, according to whether clinical signs are observed or not. The mammary gland with clinical mastitis can show signs, such as edema, tumefaction, pain, warmth, redness, and physical changes in the milk (Moreira et al., 2018). By contrast, the subclinical form is difficult to detect without any test. Currently, several on-farm tests, such as the Wisconsin Mastitis Test and the California Mastitis Test, can help in diagnosing. However, the interpretation of these tests is mainly subjective and requires trained technicians to avoid variation in results (Dingwell et al., 2003; Sanford et al., 2006; Riggio et al., 2013; Ruegg, 2017; Moroni et al., 2018). The SCC is described as a useful SCM detection method, but it uses different thresholds that represent different sensitivity (Se) and specificity (Sp) levels, and the results can be affected by several physiological factors, such as milk production level, breed, season, lactation number, and stage of lactation (Viguier et al., 2009; Jashari et al., 2016). Therefore, the definition of IMI differs from that of SCM, because IMI combines the SCC with the isolation of a pathogenic microorganism from the milk (Pyörälä, 2003).

Infrared thermography (IRT) is a passive, remote, and noninvasive technique that allows one to obtain the surface temperature of a body through the infrared radiation of the electromagnetic spectrum that it emits, wherein each pixel corresponds to a temperature intensity, where warmest areas appear white or red and coolest areas are blue or black (Eddy et al., 2001; Polat et al., 2010; Usamentiaga et al., 2014). Briefly, this diagnostic tool is based on the principles of infrared radiation, which has a longer wavelength than visible light and a shorter wavelength than microwaves. Its wavelengths range between 0.7 and $1,000 \mu \mathrm{m}$, and it is invisible to the human eye. All objects whose temperature is above absolute zero $\left(-273.15^{\circ} \mathrm{C}\right)$ emit infrared radiation proportional to their temperature, according to the Stefan-Boltzmann law via conduction convection and radiation; even cold objects emit infrared radiation, which can be absorbed, emitted, reflected, or transmitted. In that order, based on the amount of heat generated, thermal cameras acquire and process radiation and display thermal images, called thermograms (Eddy et al., 2001).

It has been described that IRT can be used for determining some physiological parameters such as breathing, stress, or estrus in cattle (Stewart et al., 2007, 2017; Talukder et al., 2014), skin and hoof in- juries (Nikkhah et al., 2005; Poikalainen et al., 2012), and subclinical diseases in calves (Schaefer et al., 2004; Lowe et al., 2016). Previous research shows that IRT can be useful to determine variations in the udder surface temperature (UST) related to milking, environmental conditions, and exercise (Berry et al., 2003), but also, IRT has had some encouraging results for the identification of mastitis, either subclinical or clinical, due to the ability of IRT to perceive changes in the UST in response to different mammary gland infections (Colak et al., 2008; Hovinen et al., 2008; Polat et al., 2010; Zaninelli et al., 2018).

The aim of this study was to evaluate the UST by IRT as a diagnostic tool for SCM and IMI, and to assess the influence of environmental conditions in the potential diagnosis of these conditions in Holstein dairy cows in herds located at high-altitude tropical regions.

\section{MATERIALS AND METHODS}

The committee on animal experimentation of the Universidad de Caldas, Manizales, Colombia, approved the protocols for image acquisition and sample collection. The cows employed in this study were used under authorization of their owners after signing an informed consent form. The personnel in charge of thermography did not have access to the results of milk analyses and vice versa; both were processed separately, and only the personnel in charge of the statistical analyses had access to the merged database.

\section{Farms and Animals}

A quarter-level analytical cross-sectional study was conducted between March and June of 2017. A total of 105 Holstein cows (397 quarters and 23 nonfunctional or blind quarters) in their first to ninth lactation were selected from 3 dairy herds in Villamaría county $\left(5^{\circ} 02^{\prime} 44^{\prime \prime} \mathrm{N} 75^{\circ} 30^{\prime} 55^{\prime \prime} \mathrm{W}\right)$, Caldas, Colombia. Herds were located at 2,100 $\mathrm{m}$ above sea level. Cows were managed under rotational grazing systems and received supplementation with concentrates according to milk yield. Predominant pasture was Kikuyu grass (Pennisetum clandestinum). Mineral supplements and water were available ad libitum.

Animals were milked twice a day, during the morning between 0200 and $0700 \mathrm{~h}$, and in the afternoon between 1230 and $1700 \mathrm{~h}$. Milk yield average was $17.8 \mathrm{~L} /$ cow per day (95\% CI: $16.7-18.6 \mathrm{~L} /$ cow per d), and cows were in late lactation, 205 DIM (95\% CI: 185-226 DIM). Milking was performed on the left or right side of the cow indiscriminately, depending on the side of the tent selected by the cow to enter (Figure 1). Additional data and environmental conditions are shown in Table 1. 
Table 1. Number of cows, quarters, and cases, and average and SE for milk yield, DIM, and environmental conditions at morning milking by farm; ranges in parentheses indicate $95 \%$ CI

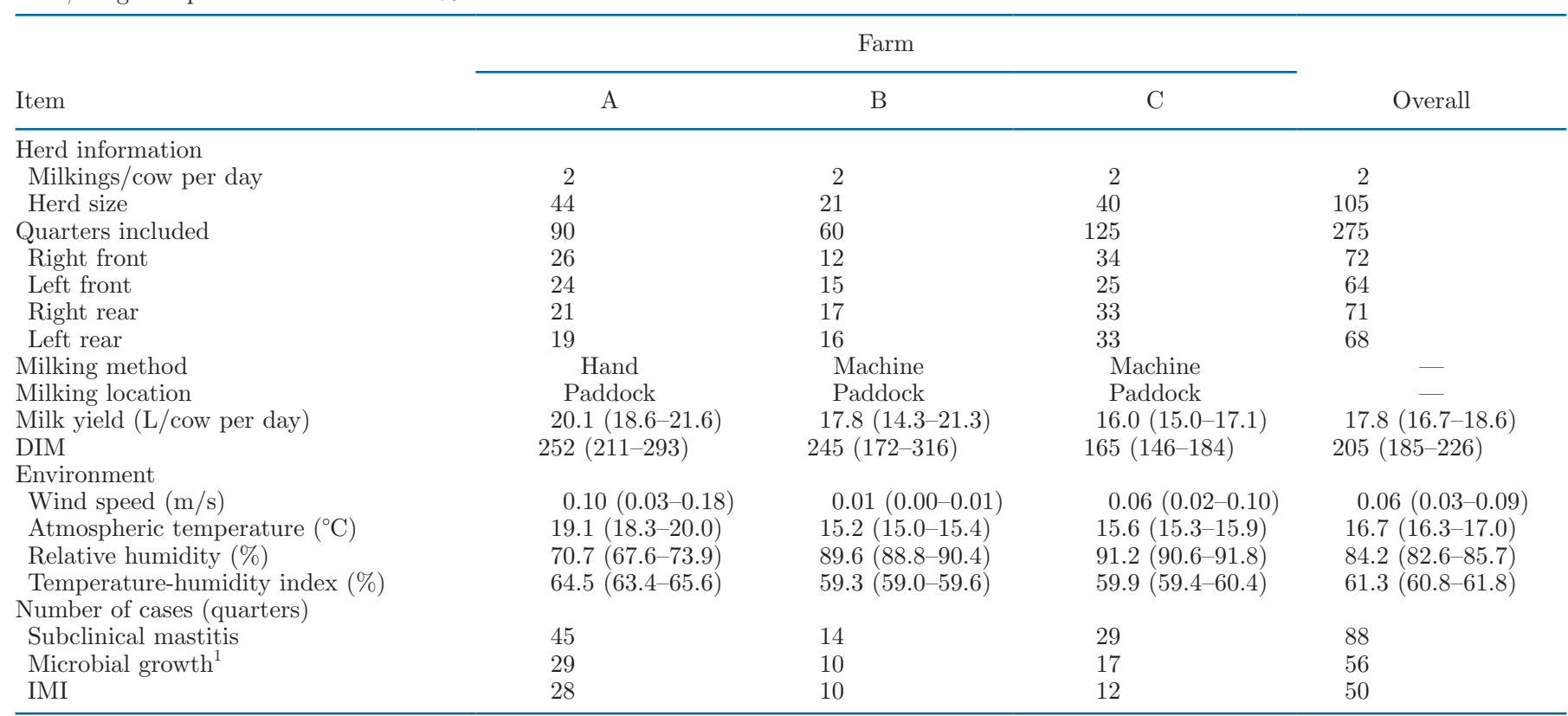

${ }^{1}$ Microbial growth case definition includes major pathogens ( $\geq 1 \mathrm{cfu}$ ) and Corynebacterium spp. ( $\left.>10 \mathrm{cfu}\right)$.

\section{Inclusion Criteria}

At the beginning of the study, all cows were clinically evaluated to determine their health status. Only healthy lactating cows that had experienced no cases of clinical mastitis in the current lactation and that had received no treatment with antibiotics for any other disease in the last $30 \mathrm{~d}$ were included. Cows with concomitant infectious diseases or showing inflammation, tumefaction, redness, or any alteration in the udder tissue, as well as visible changes in the milk such as the presence of flakes, clots, blood, or serous milk, were not included.

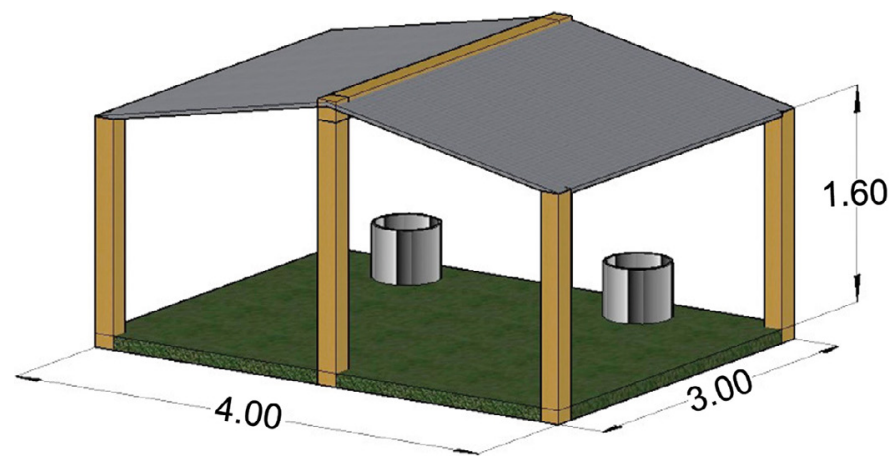

Figure 1. Diagram of temporary milking tent. Dimensions: $4 \times 3$ $\times 2 \mathrm{~m}$.

\section{Cow Preparation for IRT and Milk Sample Collection}

The udder surface of each cow was inspected for any external artifact that could affect the surface temperature, such as dirt, mud, grass, or manure that could add cold spots in the thermogram. No IRT were taken during fog or rain, because this generates a wet layer on the skin and hair of the cows that blocks the infrared radiation.

A quarter-level milk sample for bacteriological and SCC measurement was collected from every cow just before it was milked in the morning and after the IRT image was captured. For sample collection the first strips of milk were discarded, and then teat ends were disinfected using gauze soaked in alcohol before the samples were taken. A 50-mL cisternal milk sample was collected in plastic sterile tubes. Later, in the laboratory, the sample was split into 2 aliquots: one was used for microbiological diagnosis, and the other had a bronopol tablet added and was shipped under refrigeration to another laboratory for SCC measurement using an automated cell counter (Fossomatic, Foss). The SCC results were transformed into the natural logarithm $\left(\mathrm{LnSCC}, \times 10^{3}\right.$ cells $\left./ \mathrm{mL}\right)$ to normalize data distribution.

\section{IRT Protocol}

Infrared images were taken only during the morning milking before the clinical examination, and before the shot, any manipulation of the udder was avoided. 
A FLIR T450sc thermal camera (FLIR Systems Inc.) on a tripod was employed, located $1 \mathrm{~m}$ away from the objective. Also, any reflective objects in the visual field and direct sunlight were avoided. The udders were photographed under a temporary homemade tent, consisting of a plastic roof and 6 pillars without walls (dimensions $4 \times 3 \times 2 \mathrm{~m}$; Figure 1), while cows were fed with concentrate. The images were taken from the rear and lateral view. The rear image, employed for the rear quarters, was taken before the legs were tied, to obtain a better amplitude; the tail was moved to one side, so it would not interfere with the image (Figure 2, left-hand panel). The lateral view (right and left) was used only for the front quarters, and IRT was captured after tying the legs and using a dark piece of cardboard on the contralateral side, covered with a dark cloth, to avoid artifacts in the background (Figure 2, right-hand panel). Photographs were taken in the total absence of fog, to avoid mistakes in the UST measures.

To measure the UST, it was necessary to set the emissivity, relative humidity, and reflected temperature in the camera, to compensate for the effects on the udder caused by different radiation sources (Testo SE and Co., 2017).

\section{Determination of Udder Temperature}

Because the camera takes an image of the entire udder (field of view), and each pixel represents a different temperature, it is necessary to determine an average temperature for the udder. Thus, the infrared images captured by the camera were exported to the computer using FLIR Tools 5 software (FLIR Systems Inc.), after registering the emissivity, reflected temperature, distance, atmospheric temperature, and relative humidity. Later, using the ResearchIR 4.20 software (FLIR Systems Inc.), each image was upload to MatLab 2014a (MathWorks). In this software, using the tool roipoly, a manual polygonal segmentation of the region of interest was performed, resulting in a mask for the image (Figure 3); then the mask is multiplied by the original rainbow-patterned IRT, and, over the resulting region, the average, median, mode, maximum, minimum, and standard deviation of the UST were calculated by the software. Photographs of udders that show cold spots due to the presence of mud, grass, or excessive hair were removed from the database and not analyzed.

During the process, relative humidity (\%), atmospheric temperature $\left({ }^{\circ} \mathrm{C}\right)$, and wind speed $(\mathrm{m} / \mathrm{s})$ were measured using a thermo-hygro-anemometer (Extech 45160 3-in-1, Extech Instruments). Temperature-humidity index (THI) was calculated using the equation $\mathrm{THI}=(0.8 \times$ atmospheric temperature $)+[(\%$ relative humidity $\div 100) \times($ atmospheric temperature -14.4$)$ ] +46.4 , described by Mader et al. (2006).

\section{Milk Analysis}

Microbiological diagnosis was performed according to the National Mastitis Council (Hogan et al., 1999). Milk was streaked with a sterile cotton swab into blood esculin (5\% of sheep blood and $0.1 \%$ of esculin) and Edwards modified medium. Afterward, plates were incubated at $37.5^{\circ} \mathrm{C}$ and visually inspected at 24 and 48

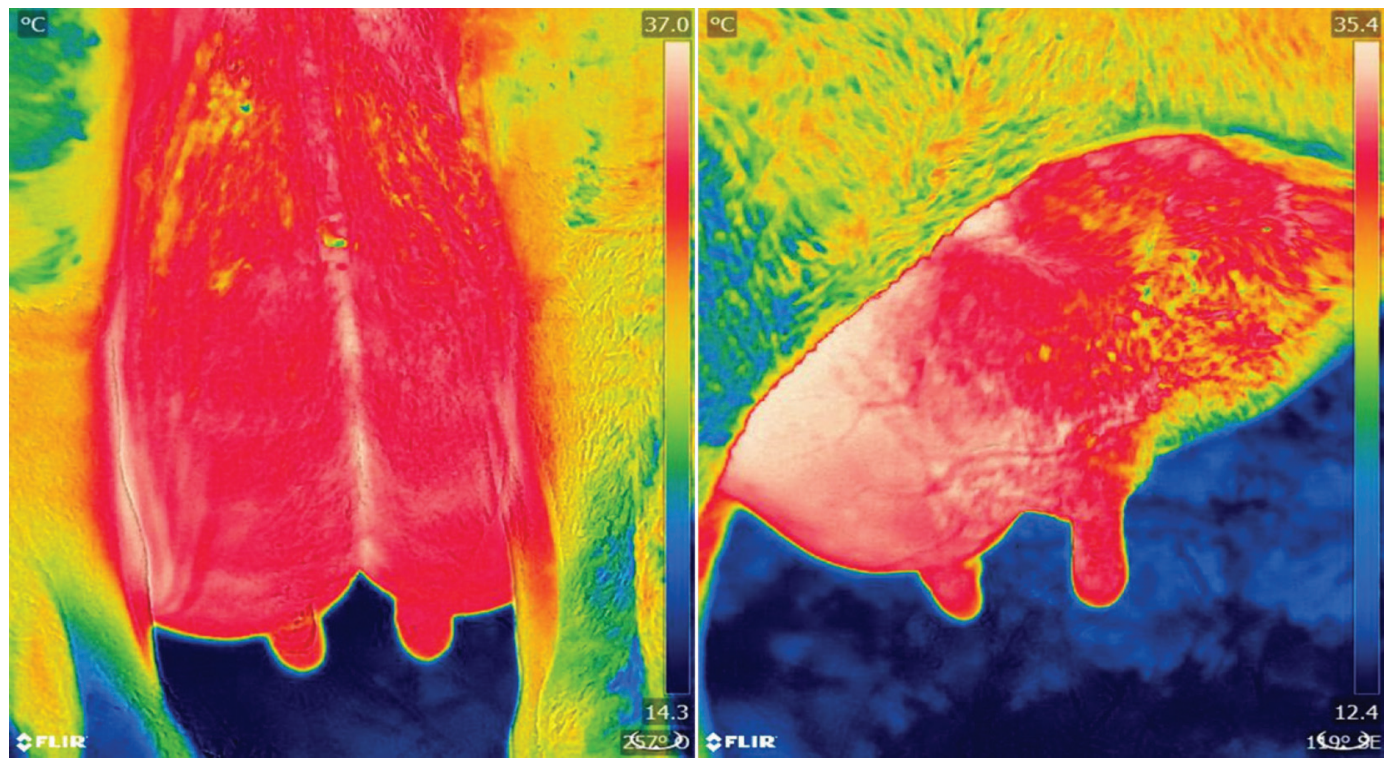

Figure 2. Infrared thermography of the udder surface temperature. Left-hand panel: rear view; right-hand panel: lateral view. 
$\mathrm{h}$ for bacterial growth. Morphology and gram-positive bacteria were identified as follows. The catalase test was used to differentiate staphylococci from streptococci. The coagulase test was performed on catalase-positive cocci to confirm Staph. aureus. Catalase-negative cocci were differentiated by their reaction to the hydrolysis of esculin under UV light. The Christie-Atkins-MunchPetersen test and esculin reaction were used to differentiate Strep. agalactiae and Streptococcus dysgalactiae, and esculin reaction and culture in enterococcosel agar were used for the identification of Strep. uberis. Morphology and Gram staining were used to identify Corynebacterium spp. Those cultures that showed more than 2 bacterial species were considered contaminated and not informative of IMI. Mixed infections were those with growth of 2 bacterial species. "No significant growth" was established when a milk sample yielded fewer than 3 colonies and no major pathogens were isolated. Staphylococcus aureus, Strep. agalactiae, Strep. dysgalactiae, and Strep. uberis were considered as major pathogens (Barkema et al., 1997; Riffon et al., 2001).

\section{Case Definition}

Three case definitions were employed. A case of SCM was diagnosed when a quarter sample had SCC $\geq 200$ $\times 10^{3}$ cells $/ \mathrm{mL}$ (Schukken et al., 2003; Dohoo et al., 2011). A microbial growth case (MG) was defined when a microbiological culture was positive for a major pathogen $(\geq 1 \mathrm{cfu} /$ plate $)$ or Corynebacterium spp. $(\geq 10$ cfu/plate; Gonçalves et al., 2018). Finally, IMI was defined as the presence of MG and SCC $\geq 100 \times 10^{3}$ cells/ mL (Hamann, 2003; Pyörälä, 2003). Quarters without a case of SCM, MG, or IMI were analyzed as a control group.

\section{Statistical Analysis}

The association of UST and environmental and microbiological variables was explored through a multilevel mixed effects linear regression model clustered within cows and herd. All the bacteria found and the variables shown in Table 1 (categorical variables: milking method, milking location; continuous variables: herd size, milk yield, DIM, wind speed, atmospheric temperature, relative humidity, and THI) were evaluated as model predictors. Three models were assessed according to each case definition; thus, an unconditional analysis was conducted, and variables with $P \leq$ 0.15 were included in the initial model. The final model was built with backward manual elimination procedure with significance level $\leq 0.05$ as cutoff to be retained
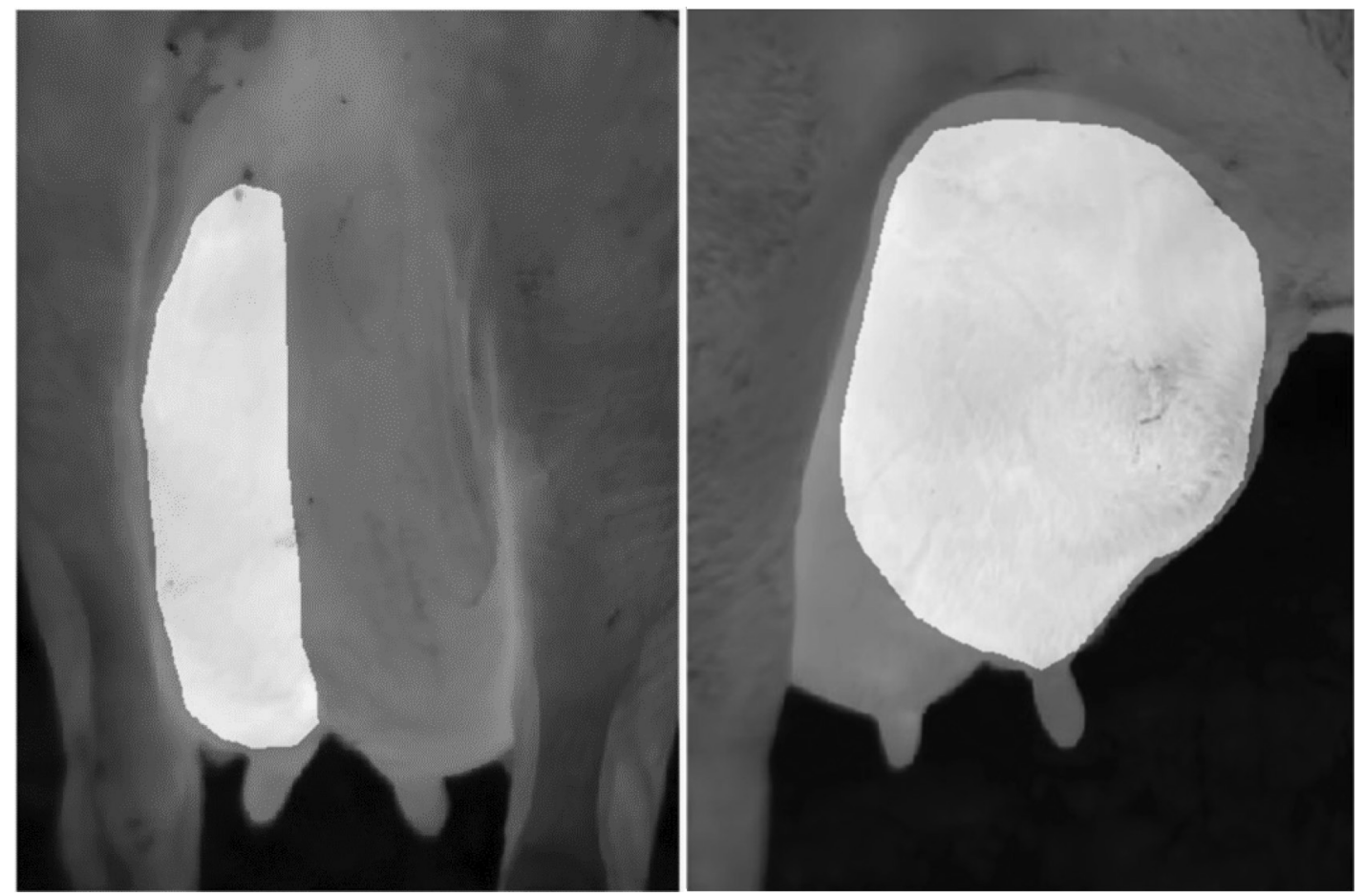

Figure 3. Region of interest of the left rear (left-hand panel) and right front (right-hand panel) quarters of the udder. The light patch corresponds to the manual segmentation (mask). 
in the model. The model was evaluated via analysis of the residuals at the lowest level (quarter). Milking method was one of the factors influencing the outcome; hence, analyses including all cow quarters milked by hand were performed separately from machine-milking quarters.

Sensitivity was calculated as the probability of a positive test result given that the disease is present, and $\mathrm{Sp}$ as the probability of obtaining a negative test result given that the disease is absent (Dohoo et al., 2009; Ying et al., 2020). For several cutoff points, the Youden index (YI) was calculated as the maximum expression for $\mathrm{Se}+\mathrm{Sp}-1$, and the value of the cutoff point that achieved the maximum YI was considered the optimal threshold (Fluss et al., 2005; Kandeel et al., 2019). For the same cutoff points mentioned, the positive likelihood ratio $(+\mathbf{L R})$ was obtained by the computation of Se/(1 - Sp); values from 5 to 10 represent a moderate effect on post-test probability, and $+\mathrm{LR}>10$ were considered to be good (or large), increasing the post-test probability of diagnosis (Hayden and Brown, 1999; Grimes and Schulz, 2005). Also, the area under the curve (AUC) was obtained for several cutoff points. According to the YI, the UST threshold was selected, and receiver operating characteristic (ROC) curves were calculated for each case definition threshold and were compared using a nonparametric test for equality for ROC AUC (DeLong et al., 1988). Finally, the Cohen's kappa coefficient ( $\boldsymbol{\kappa}$ ) was calculated to determine the agreement beyond chance among the optimum cutoff points for each case definition and the IRT. The SCM case definition (microbiological analysis and SCC measurement) was considered as a reference method. A $\kappa$ value between 0 and 0.2 was considered slight, 0.2 to 0.4 fair, 0.4 to 0.6 moderate, 0.6 to 0.8 substantial, and $>0.8$ excellent agreement (Landis and Koch, 1977). The positive and negative predictive values are not reported, due to their relation with prevalence in the population included in the study (Dohoo et al., 2009).

Somatic cell count values were log-transformed during analyses and back-transformed to be presented as regular units (cells $/ \mathrm{mL})$. All the analyses were carried out using a statistical software epidemiological functions (xtmixed, ttest, diagt, roccomp, rocfit, kap, and kapci; Stata 14.2, Stata Corp.), and statistical significance was declared at $P<0.05$.

\section{RESULTS}

A total of $275(69.3 \%)$ quarters were included and analyzed in the study; $122(30.7 \%)$ were not analyzed in this study because cows or udders were in contact with mud during rainy season and udders were not entirely clean. Dirt or mud add cold spots to the IRT and alter the results obtained with this technology.

Microbiological diagnosis showed that CNS were the most frequent bacteria $(\mathrm{n}=53,19.3 \%)$, followed by Staph. aureus $(\mathrm{n}=24,8.7 \%)$, Strep. uberis ( $\mathrm{n}=$ $22,8.0 \%)$, and Corynebacterium spp. $(\mathrm{n}=20,7.3 \%$; Table 2). Major pathogens were isolated in 45 samples (16.4\%). We detected no difference among the SCM cases by quarters: right front $15.3 \%$ (95\% CI: 6.8 $24.8 \%$ ), left front $20.3 \%$ (95\% CI: $10.2-30.4 \%$ ), right rear $21.1 \%$ (95\% CI: $11.4-30.9 \%$ ), left rear $13.2 \%$ (95\% CI: $5.0-21.5 \% ; P=0.55)$. The average of $\mathrm{LnSCC}$ was $4.6 \times 10^{3}$ cells $/ \mathrm{mL}\left(95 \%\right.$ CI: $4.4-4.8 \times 10^{3}$ cells $/ \mathrm{mL}$; equivalent to 102,500 cells $/ \mathrm{mL}$ ).

Table 2. Microbiological diagnosis of 275 quarter milk samples grouped by the 3 case definitions, and SCC mean (with $95 \%$ CI) ${ }^{1}$

\begin{tabular}{|c|c|c|c|c|c|}
\hline Microbiologic diagnosis & $\begin{array}{l}\text { Isolates, } \\
\text { n }(\%)\end{array}$ & $\begin{array}{c}\text { SCC, } \\
\text { mean }(95 \% \text { CI })\end{array}$ & \multicolumn{3}{|c|}{ Cases, ${ }^{2} \mathrm{n}$} \\
\hline \multicolumn{6}{|l|}{ Major pathogens } \\
\hline Staphylococcus aureus & $24(8.7)$ & $756(462-1,234)^{\mathrm{a}}$ & 23 & 24 & 23 \\
\hline Streptococcus agalactiae & $1(0.4)$ & $567^{3}$ & 1 & 1 & 1 \\
\hline Streptococcus uberis & $22(8.0)$ & $1,094(544-2,199)^{\mathrm{a}}$ & 20 & 22 & 20 \\
\hline \multicolumn{6}{|l|}{ Other pathogens } \\
\hline$\geq 10 \mathrm{cfu}$ & $11(4.0)$ & $174(78-386)^{\mathrm{b}}$ & 6 & 11 & 0 \\
\hline CNS & $53(19.3)$ & $134(81-219)^{\mathrm{b}}$ & 22 & $\begin{array}{r}11 \\
0\end{array}$ & 0 \\
\hline Streptococcus spp. & $10(3.6)$ & $801(223-2,884)^{\mathrm{ac}}$ & 7 & 0 & 0 \\
\hline Mixed infections & $125(45.5)$ & $67(37-122)^{\text {ac }}$ & 11 & 8 & 8 \\
\hline No growth or no significant growth & $158(57.5)$ & $52(42-64)^{d}$ & 20 & 0 & 0 \\
\hline
\end{tabular}

\footnotetext{
${ }^{\mathrm{a}-\mathrm{d}}$ Bacterial species with different superscript letters differ in LnSCC $(P<0.05)$.

${ }^{1} \mathrm{SCC}$ mean and $95 \%$ CI values are presented back-transformed from the natural logarithm of SCC (LnSCC).

${ }^{2} \mathrm{MG}=$ microbial growth; $\mathrm{SCM}=$ subclinical mastitis.

${ }^{3}$ The CI could not be calculated for Strep. agalactiae because there was only 1 sample.
} 
Table 3. Final mixed effects linear regression model of surface udder temperature $\left({ }^{\circ} \mathrm{C}\right)$ by infrared thermography, clustered by cows and herds

\begin{tabular}{|c|c|c|c|c|c|}
\hline \multirow{2}{*}{$\begin{array}{l}\text { Predictor }^{1} \\
\text { Case definition, SCM: SCC }>200 \times 10^{3} \text { cells } / \mathrm{mL}\end{array}$} & \multirow[t]{2}{*}{ Coefficient } & \multirow[t]{2}{*}{ SE } & \multirow[t]{2}{*}{$P$-value } & \multicolumn{2}{|c|}{$95 \% \mathrm{CI}$} \\
\hline & & & & & \\
\hline Milking method & 1.06 & 0.14 & 0.00 & 0.78 & 1.34 \\
\hline \multicolumn{6}{|c|}{ Random effects parameters } \\
\hline Herd (variance) & 0.00 & 0.00 & & 0.00 & 6.65 \\
\hline Cow (variance) & 0.35 & 0.07 & & 0.23 & 0.53 \\
\hline Milking method & 0.98 & 0.14 & 0.00 & 0.71 & 1.25 \\
\hline MG cases & 1.07 & 0.11 & 0.00 & 0.86 & 1.29 \\
\hline Intercept & 31.75 & 0.11 & 0.00 & 31.53 & 31.97 \\
\hline \multicolumn{6}{|c|}{ Random effects parameters } \\
\hline Herd (variance) & 0.00 & 0.00 & & 0.00 & $1,524.22$ \\
\hline Cow (variance) & 0.31 & 0.07 & & 0.20 & 0.48 \\
\hline \multicolumn{6}{|c|}{ Random effects parameters } \\
\hline Herd (variance) & 0.00 & 0.00 & & 0.00 & $66,097.91$ \\
\hline Cow (variance) & 0.35 & 0.07 & & 0.23 & 0.52 \\
\hline Residual (variance) & 0.36 & 0.04 & & 0.29 & 0.44 \\
\hline
\end{tabular}

${ }^{1} \mathrm{SCM}=$ subclinical mastitis; $\mathrm{MG}=$ microbial growth.

\section{Subclinical Mastitis, Microbial Growth, and IMI}

Subclinical mastitis was diagnosed in 45 cases in farm A (manual milking) and 43 cases in farms B and C (machine milking), for a total of 88 cases according to the definition in the Materials and Methods section. Average SCC for quarters with SCM was $874.6 \times$ $10^{3}$ cells $/ \mathrm{mL}\left(95 \%\right.$ CI: $696.8-1,097.7 \times 10^{3}$ cells $\left./ \mathrm{mL}\right)$, against $37.5 \times 10^{3}$ cells $/ \mathrm{mL}\left(95 \%\right.$ CI: $32.8-42.9 \times 10^{3}$ cells $/ \mathrm{mL}$ ) in healthy quarters. Microbial growth cases were observed in 56 quarters; of those, 29 occurred in hand-milked quarters and 27 in machine-milked quarters. The SCC in MG quarters was $647.5 \times 10^{3}$ cells/ $\mathrm{mL}\left(95 \%\right.$ CI: $434.7-964.1 \times 10^{3}$ cells $\left./ \mathrm{mL}\right)$, against 64.1 $\times 10^{3}$ cells $/ \mathrm{mL}\left(95 \%\right.$ CI: $52.5-78.4 \times 10^{3}$ cells $\left./ \mathrm{mL}\right)$ in quarters without MG. Finally, IMI was declared in 50 cases: 28 on farm A, and 22 on farms B and C. Average SCC in cows with IMI was $915.4 \times 10^{3}$ cells $/ \mathrm{mL}$ (95\% CI: $661.3-1,267.3 \times 10^{3}$ cells $\left./ \mathrm{mL}\right)$, against 63.2 $\times 10^{3}$ cells $/ \mathrm{mL}\left(95 \%\right.$ CI: $51.9-76.8 \times 10^{3}$ cells $\left./ \mathrm{mL}\right)$ in healthy quarters. In addition, SCC according to the microorganism isolated is presented in Table 2.

\section{IRT and Mixed Effects Linear Regression Model}

The average UST of cow quarters enrolled in the study was $32.6^{\circ} \mathrm{C}\left(95 \%\right.$ CI: $\left.32.5-32.8^{\circ} \mathrm{C}\right)$, whereas cow quarters with SCM had $32.9^{\circ} \mathrm{C}\left(95 \%\right.$ CI: $\left.32.7-33.1^{\circ} \mathrm{C}\right)$, MG cases $33.5^{\circ} \mathrm{C}\left(95 \%\right.$ CI: $\left.33.3-33.7^{\circ} \mathrm{C}\right)$, and IMI UST was $33.5^{\circ} \mathrm{C}\left(95 \%\right.$ CI: $\left.33.2-33.7^{\circ} \mathrm{C}\right)$. Additionally, UST of quarters without a case declaration ranged between (95\% CI) 32.4 to $32.6^{\circ} \mathrm{C}(P<0.001)$. The final mixed effects linear regression models, one for each case declaration, included as predictor the milking method and the case declaration in MG and IMI; however, SCM was the only case declaration that was not retained in the final model, being replaced by the presence of major pathogens. The coefficients of the final models are shown in Table 3. No environmental variables were found related to UST.

\section{Receiver Operating Characteristics}

The optimum cutoff point selected for the UST in hand-milked quarters was $32.6^{\circ} \mathrm{C}$ for all case definitions. At this UST threshold, SCM had $\mathrm{Se}=0.53, \mathrm{Sp}=0.89$, $\mathrm{AUC}=0.71, \mathrm{YI}=0.42$, and $+\mathrm{LR}=4.6 ; \mathrm{MG}$ values were $\mathrm{Se}=0.83, \mathrm{Sp}=0.93, \mathrm{AUC}=0.88, \mathrm{YI}=0.76$, and $+\mathrm{LR}=12.6$; and IMI had $\mathrm{Se}=0.82, \mathrm{Sp}=0.92$, $\mathrm{AUC}=0.87, \mathrm{YI}=0.74$, and $+\mathrm{LR}=10.2($ Table 4$) . \mathrm{In}$ addition, optimum thresholds for UST in machine milking were different according to the case definition. The SCM and IMI threshold was $34.0^{\circ} \mathrm{C}$, and MG was set at $33.7^{\circ} \mathrm{C}$. In this respect, $\mathrm{SCM}$ values were $\mathrm{Se}=0.42, \mathrm{Sp}$ $=0.97, \mathrm{AUC}=0.70, \mathrm{YI}=0.39$, and $+\mathrm{LR}=14.9 ; \mathrm{MG}$ had $\mathrm{Se}=0.82, \mathrm{Sp}=0.89, \mathrm{AUC}=0.85, \mathrm{YI}=0.70$, and $+\mathrm{LR}=7.15$; and IMI had $\mathrm{Se}=0.82, \mathrm{Sp}=0.98, \mathrm{AUC}$ $=0.90, \mathrm{YI}=0.79$, and $+\mathrm{LR}=33.3$. This information 
Table 4. Sensitivity, specificity, area under the curve (AUC), Youden index (YI), and positive likelihood ratio $(+\mathrm{LR})$ at different udder surface temperature cutoff points $\left({ }^{\circ} \mathrm{C}\right)$ by infrared thermography, grouped by 3 case definitions

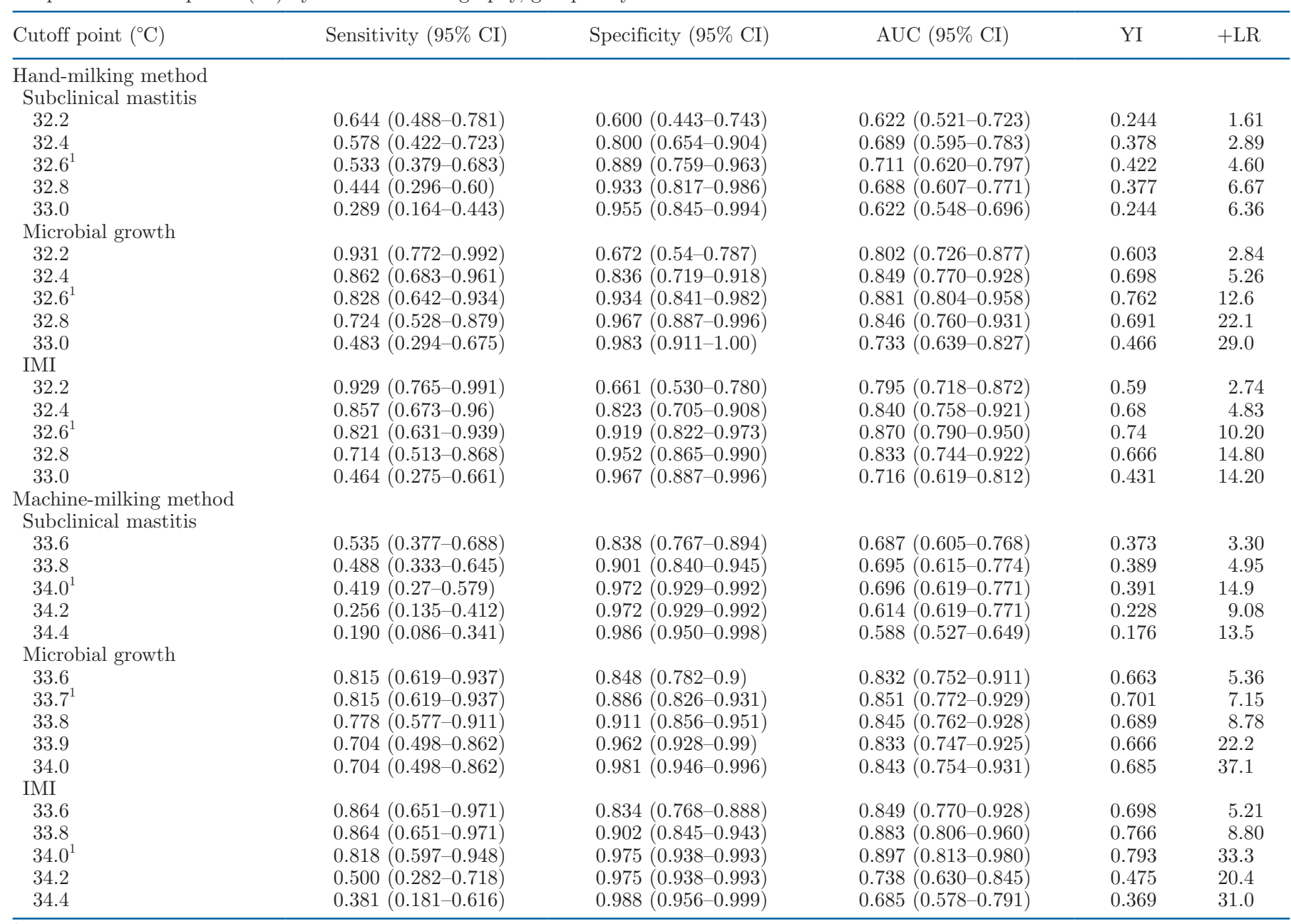

${ }^{1}$ Cutoff point with the largest AUC and YI values in each category.

is expanded in Table 4. In addition, the Se-Sp plots of maximum Se and Sp obtained for each case definition are presented in Figure 4. Furthermore, the ROC analysis of selected thresholds showed that SCM AUC was significantly lower than those of MG and IMI $(P<$ 0.001 ) for hand and machine milking; however, AUC of MG and IMI were similar for both milking methods $(P$ $>0.05$; Figure 5).

\section{Agreement of the Tests}

The observed agreements between SCM, MG, and IMI case definitions methods and the UST obtained by IRT with a cutoff point equal to $32.6^{\circ} \mathrm{C}$ for hand milking were $70.0,90.0$, and $88.9 \%$, respectively. In that order, the math for Cohen's kappa coefficient showed moderate agreement between UST and SCM $(\kappa=0.40$; 95\% CI: $0.23-0.58$ ) and substantial agreement in MG $(\kappa=0.77 ; 95 \%$ CI: $0.63-0.91)$ and IMI $(\kappa=0.74 ; 95 \%$ CI: 0.59-0.89) case definitions with UST. In the same way, in quarters milked by machine, the diagnosis of SCM and IMI using UST with a cutoff point of $34.0^{\circ} \mathrm{C}$ showed observed agreement of $84.3 \%$ and $95.7 \%$, respectively. Hence, SCM ( $\kappa=0.47 ; 95 \%$ CI: $0.31-0.62)$ showed moderate agreement, whereas IMI agreement was substantial $(\kappa=0.79 ; 95 \%$ CI: $0.66-0.93)$. The MG observed agreement was $87.6 \%$, with moderate agreement between the tests ( $\kappa=0.60 ; 95 \%$ CI: $0.45-0.75)$. All $\kappa$ were higher than would be expected due to chance $(P<0.001)$.

\section{DISCUSSION}

As mentioned, several studies have evaluated IRT as a diagnostic tool for mastitis, either clinical, subclinical, or IMI, in dairy cattle. However, these studies 


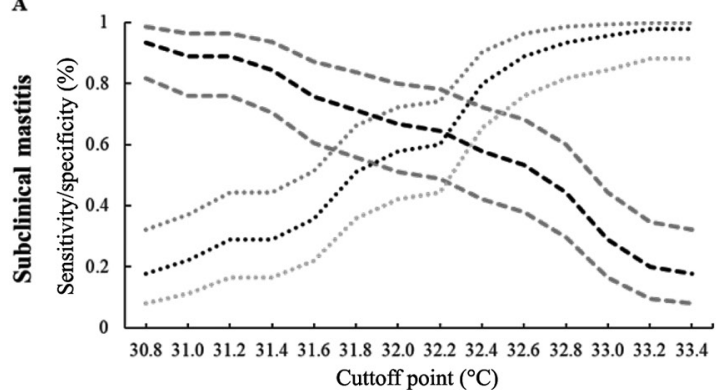

C

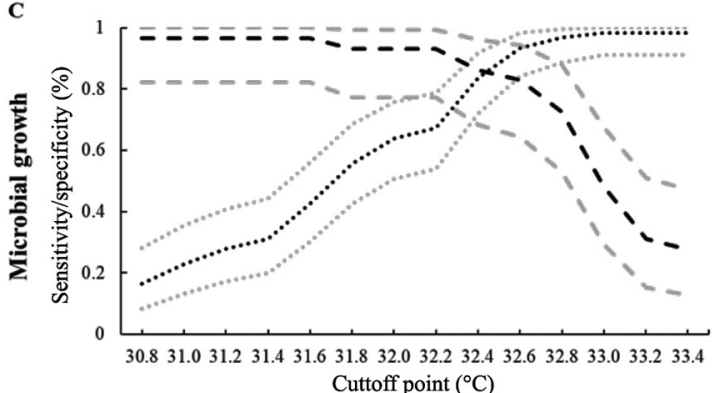

$\mathbf{E}$

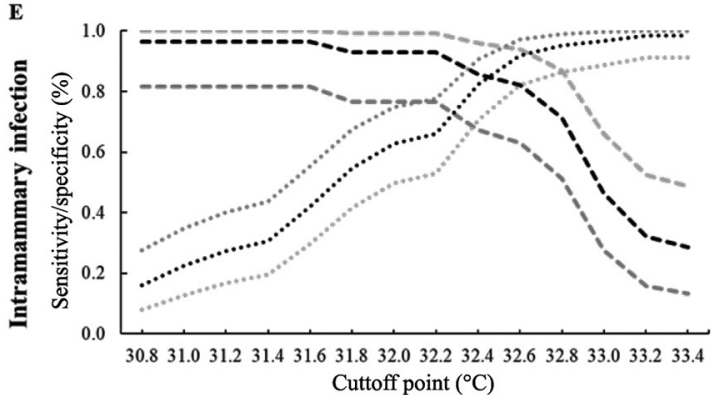

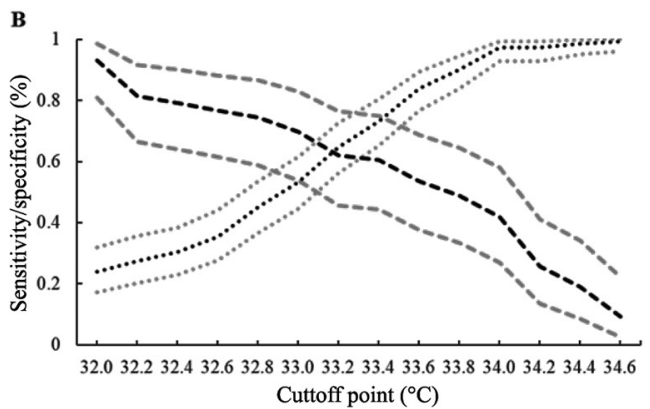
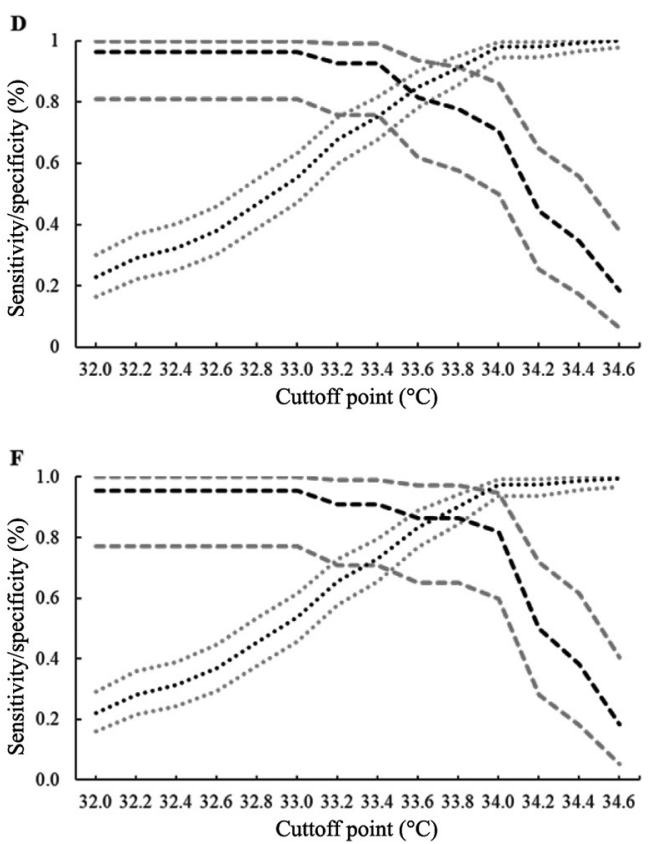

Figure 4. Sensitivity (dashed line) and specificity (dotted line) plot (with $95 \%$ CI; gray lines) of udder surface temperature ( ${ }^{\circ} \mathrm{C}$ ) as a predictor of subclinical mastitis according to 3 case definitions, when milking method was by hand (left-hand column) or machine (right-hand column).

were performed under weather-controlled conditions in milking parlors, which limits the practical value in field conditions (Colak et al., 2008; Polat et al., 2010). In line with this, we intend to perform a study in the usual environmental and topographical conditions in which our dairy cattle are routinely milked and managed.

The most frequently detected bacteria were CNS; despite the variety of species of CNS, they were classified as one homogeneous group. In this study $41.5 \%$ $(\mathrm{n}=22)$ of samples with CNS showed SCC over the SCM threshold $\left(200 \times 10^{3}\right.$ cells $\left./ \mathrm{mL}\right)$, and $58.5 \%(\mathrm{n}$ $=31$ ) of CNS samples had SCC above the threshold value selected for this research. In fact, the most frequent CNS are evenly distributed between high and low SCC (Thorberg et al., 2009; Condas et al., 2017). By contrast, Staph. aureus-positive milk samples had SCC values over the threshold (SCM or IMI) in $95.8 \%$ of cases $(\mathrm{n}=23)$, in accord with previous findings, where a positive correlation between them has been described (Djabri et al., 2002; Jayarao et al., 2004; Barkema et al., 2015). Likewise, in $90.1 \%$ of the quarter milk samples where Strep. uberis was isolated, SCM and an IMI were diagnosed. Finally, the respective low and zero prevalences of Strep. agalactiae and Strep. dysgalactiae prevented the analysis of this group of bacteria separately, in accord with previous studies developed in Colombia. The zero prevalence of Strep. dysgalactiae is expected because this pathogen is rarely isolated from milk quarter samples in the country, with prevalence reports ranging from 0.6 to $5.2 \%$ (Ramírez et al., 2001, 2014; Velasco-Bolaños et al., 2019).

All IRT were taken during the predawn $(0200 \mathrm{~h})$ and morning hours (0700 h), avoiding the hours of maximum solar radiation and heat, because solar radiation along with low wind speed can increase an animal's heat load (Mader et al., 2006) and therefore affect UST. How- 
ever, to improve udder temperature measurement, the high-resolution thermal camera included environmental parameters.

It has been described that IRT is highly dependent on working conditions such as wind speed, humidity, or environmental temperature; likewise, UST can be affected by external factors when animals are not in controlled environmental conditions (Berry et al., 2003; Polat et al., 2010; Porcionato et al., 2010). Unconditional analysis between several environmental factors showed that none of them were associated with UST; nevertheless, when mixed effects linear regression analysis was performed, the environmental factors were not present in the final model as a predictor of UST. Those results suggest that environmental factors in grazing systems are not related to UST if environmental factors are controlled when the IRT is taken. It is worth mentioning that animals included in this study were milked directly in the paddocks where cows were on pasture, using portable machine milking systems or by hand; they did not have to walk long distances to the milking parlor, and no resting period was needed because friction generated with the displacement was not a factor to be controlled, as was done in other studies (Berry et al., 2003; Colak et al., 2008; Polat et al., 2010). The maximum distance walked to the milking tent by the cows included in this study was less than $50 \mathrm{~m}$; however, on some farms in tropical countries, including Colombia, cows must walk long distances from the paddocks to a waiting room and then into the milking parlor. According to other authors, this exercise could affect UST and should be considered a confounder in other studies aiming at using UST for mastitis diagnosis (Berry et al., 2003).

The THI, which combines relative humidity and environmental temperature, was reported as a factor directly associated with surface corporal temperature of cattle, including UST (Peng et al., 2019). Nasr and El-Tarabany (2017) also describe that THI could increase related to the increase of SCC. During the entire period that the measurements of our study were taken, THI was below 72 points; this could be interpreted as thermoneutral conditions for the animals, where heat stress should not appear and cattle's body thermoregulation ability would be unaffected (Dash et al., 2016).

The average UST in this study was similar to those reported in cows from Estonia, Canada, and Brazil (Berry et al., 2003; Porcionato et al., 2009; Poikalainen et al., 2012; Silva et al., 2019); however, some researchers have found average temperatures of $>34^{\circ} \mathrm{C}$ in Europe and Asia (Colak et al., 2008; Zaninelli et al., 2018; Peng et al., 2019).

Two factors affected UST in our study, one of which was the milking method. The UST in machine milking was close to $1.0^{\circ} \mathrm{C}$ (Table 3 ) warmer than that of udders milked by hand, regardless of the case definition. This is the first report finding such a difference, as all previous reports, according to our literature review, were done with machine milking. However, the specific mechanism involved in the observed relationship between milking method and UST response are not known, and it would
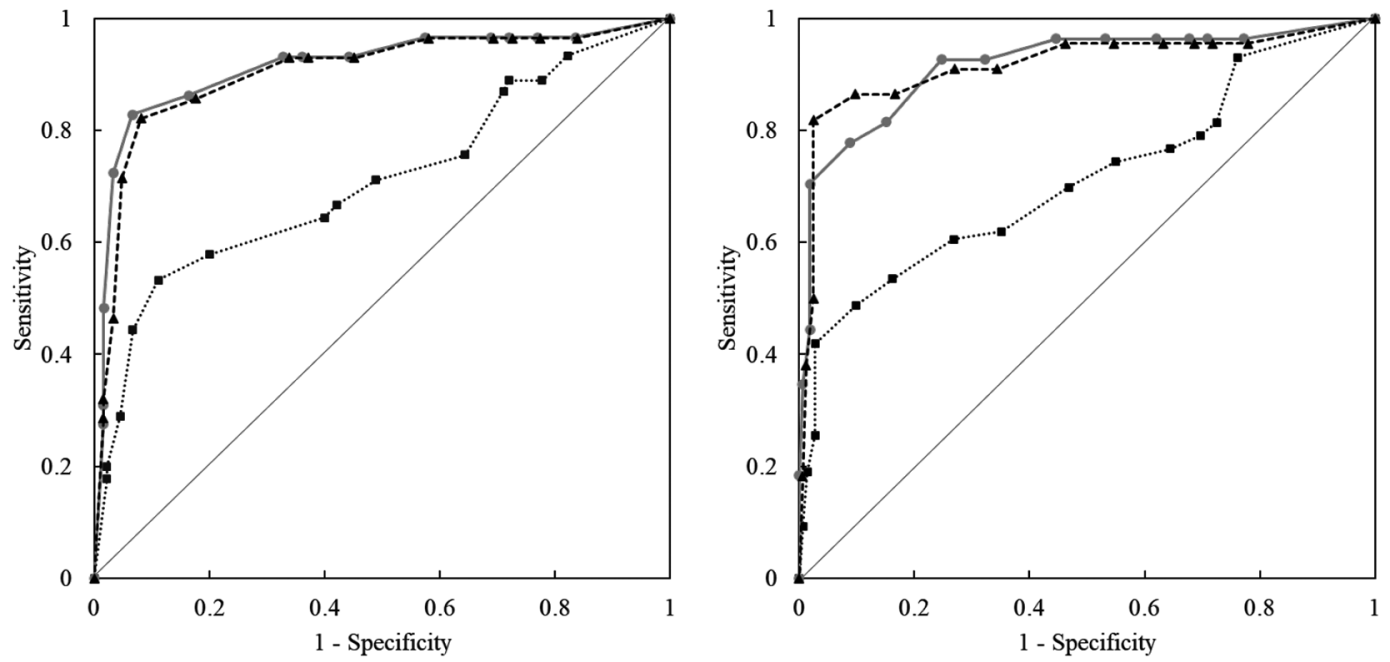

Figure 5. Left-hand panel: Receiver operating characteristics (ROC) analysis for udder surface temperature (UST, $\left.{ }^{\circ} \mathrm{C}\right)$ to assess the capac-

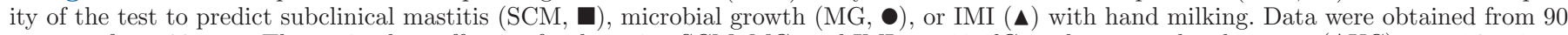
quarters from 44 cows. The optimal cutoff point for detecting SCM, MG, and IMI was $32.6^{\circ} \mathrm{C}$, and areas under the curve (AUC) were $0.71,0.88$, and 0.87 for SCM, MG, and IMI, respectively. Right-hand panel: ROC analysis for UST to assess the capacity of the test to predict SCM (ם), MG (๑), and IMI $(\boldsymbol{\Delta})$ with machine milking. These data were obtained from 185 quarters from 61 cows. The optimal cutoff points for detecting $\mathrm{SCM}$ and IMI were $34.0^{\circ} \mathrm{C}$ and $33.7^{\circ} \mathrm{C}$ for $\mathrm{MG}$, and the AUC was $0.70,0.85$, and 0.90 for SCM, MG, and IMI, respectively. The diagonal line represents the ROC curve for a test of no predictive ability. 
be necessary to determine which specific factors in the milking method are responsible for these results. One hypothesis could be related to the udder distance from the ground, as higher udders with smaller teats are found commonly on machine-milking farms. Such udders are more influenced by body temperature radiation because they are also closer to the cow than those from farms were cows were milked by hand, where cows typically have large udders and long teats, closer to the ground, where they can easily release heat. Nonetheless, this parameter was not measured in this study.

The other aspect related to UST was MG and IMI: IMI leads to variation in skin vasomotor activity, with vasodilation and blood cell perfusion (mainly influx of leukocytes to the site of the infection) resulting in hyperemia, which leads to temperature fluctuation that can be detected by IRT (Hovinen et al., 2008; Viguier et al., 2009). This can also explain why healthy udders are cooler than those diagnosed as an MG or IMI case. The SCM case definition was not related to UST and was excluded from the final model. Instead, the presence of major pathogens remained in the model, and the coefficient indicates that these increase the UST by $1.16^{\circ} \mathrm{C}$.

Our study compares UST for diagnosis of SCM, MG, and IMI. Based on our results for Sp, Se, AUC, YI, and $+\mathrm{LR}$, we suggest that SCM is not well identified by UST, and that an important number of SCM quarters will not be diagnosed by the UST method; however, MG and IMI show encouraging results for UST as a diagnostic tool, based on those diagnostic test evaluations when the optimum threshold was used for either hand or machine milking under field conditions. According to Kandeel et al. (2019), diagnostic tests should have Se and Sp as high as possible, AUC $>0.80$, and +LR > 10; in our study, the UST cutoff point selected to diagnose IMI fulfilled all those indices, suggesting that UST had good performance. In this regard, we can suggest, like other authors, that an evident relation exists between mammary gland health and UST as measured by IRT (Metzner et al., 2014; Zaninelli et al., 2018), and, according to our findings, UST could be a reliable method for diagnosis of IMI and, to a lesser degree, of MG.

Because Se, Sp, AUC, and +LR of IRT depend on the threshold used, practitioners could select the cutoff point to modify one of the mentioned parameters, to increase the probability of isolating healthy animals in large herds with high prevalence of SCM (Sp), the probability of identifying all the SCM in the herd (Se), or the probability of the post-test diagnosis (+LR; Hayden and Brown, 1999; Stokes et al., 2012). In this study, UST had high Se and Sp values for diagnosing MG or IMI, but the values obtained for SCM, defined as an $\mathrm{SCC}>200 \times 10^{3}$ cells $/ \mathrm{mL}$, were not reliable, in either hand or machine milking. Additionally, differences were observed between the AUC ROC analyses according to the case definition, where SCM had lower values compared with UST as a tool for diagnosing MG and IMI, and these latter showed similar values of AUC.

The maximum AUC obtained for the threshold value for UST, for hand and machine milking, and the Se and Sp differed from those reported by Polat et al. (2010) in Brown Swiss dairy cows with SCM definition similar to our study $(\mathrm{Se}=0.83, \mathrm{Sp}=1.00, \mathrm{AUC}=0.91)$. In addition, our findings for IMI were higher than those reported by Zaninelli et al. (2018), in which the AUC, Se, and Sp were, respectively, 0.80, 0.79, and 0.78. In addition, Polat et al. (2010) and Zaninelli et al. (2018) used an SCC threshold of $400 \times 10^{3}$ cells $/ \mathrm{mL}$ to define an SCM case. For Zaninelli et al. (2018), this resulted in a detrimental effect over AUC, Se, and Sp, whereas Polat et al. (2010) showed better values for AUC and Se but a considerable decrease in Sp, as expected.

The kappa coefficient found in our study indicated substantial agreement between UST and MG and IMI for hand and machine milking, but only moderate agreement for the SCM case definition (in both hand and machine milking). The substantial agreement could be described as clinically useful according to Dohoo et al. (2009). However, as described in Torres et al. (2009), the kappa coefficient depends on Se, Sp, and distribution of the prevalence; thus, when an unbalanced low prevalence appears, kappa results can be low despite relatively good agreement (Thompson and Walter, 1988; Cicchetti and Feinstein, 1990). Accordingly, kappa can be underestimated for machine-milking farms due to the low prevalence of SCM, MG, and IMI case declarations $(<23 \%)$.

According to several authors, IRT could be described as a noninvasive early-detection method with enough potential to diagnose mastitis (Colak et al., 2008; Hovinen et al., 2008; Polat et al., 2010; Zaninelli et al., 2018). Nevertheless, no standardized method currently exists to capture IRT, including distance from the objective, which ranges from 0.5 to $2 \mathrm{~m}$ (Porcionato et al., 2009; Nakagawa et al., 2016; Pampariene et al., 2016); the region of interest, which may or may not include the teat, the teat end (Barth, 2000; Porcionato et al., 2009), the whole udder (Hovinen et al., 2008; Polat et al., 2010; Poikalainen et al., 2012), and the lower, median, and upper fractions of the udder (Porcionato et al., 2009; Sathiyabarathi et al., 2016); and the view (front, rear, or lateral). Additionally, region of interest can be defined using rectangles, lines, or polygons (Metzner et al., 2014). In this study, from both IRT images an average UST value was found by using a 
manual polygon segmentation of the udder, which was described as reliable by Metzner et al. (2014). Additionally, there is no consensus in the UST average or in the cutoff point, and currently there is lack of agreement over the UST value to be used for diagnosis (average, maximum, or median; Polat et al., 2010; Metzner et al., 2015; Zaninelli et al., 2018) and the moment of the IRT image capture, whether before or after sample collection. Porcionato et al. (2009) performed IRT after sampling and found a lack of association between UST and SCM; based on that result, it could be that the previous manipulation of the udder increases the UST evenly in all teats due to heat transfer from the technician's hand to the udder and the friction that occurs during milk sampling, which may mask the true surface temperature. All of this is without mentioning the variety of thermal cameras and software for thermal image analysis employed in existing research.

Finally, some concerns exist about the implementation of IRT for measuring UST, not due to test performance but because it is a nonstandardized test, although its relationship with mammary gland health status and usefulness have been demonstrated several times (Polat et al., 2010; Metzner et al., 2014; Zaninelli et al., 2018). However, currently useful common methods exist, such as the California Mastitis Test, which is a low-cost, fast, portable, and accurate technique for mastitis diagnosis (Polat et al., 2010; Kandeel et al., 2019).

\section{CONCLUSIONS}

The findings of this research suggest that UST established by IRT was not related to SCM cases as defined in this study. Additionally, UST was 1.07 and $1.10^{\circ} \mathrm{C}$ higher in quarters with MG and IMI, respectively, than in healthy quarters; therefore, UST is a reliable and clinically useful method for MG and IMI diagnosis on grazing systems in tropical pastures, with animals milked by either hand or machine. However, milking method is an important factor when UST is used. In addition, there was no effect of environmental conditions on the UST.

\section{ACKNOWLEDGMENTS}

We thank all the farmers, milkers, and management personnel involved in the experimental data collection for this study. We also thank the Agrarian Sciences $\mathrm{PhD}$ Program at the Universidad de Caldas for the financial support for the publication of the results and the Gobernación de Caldas. This research was supported by the Universidad de Caldas, the Universidad
Nacional de Colombia (Manizales), the Convocatoria Conjunta Para Proyectos de Investigación e Innovación, and the Convocatoria Nacional de Proyectos Para el Fortalecimiento de la Investigación, Creación e Innovación de la Universidad Nacional de Colombia 2016-2018, Grant No. 0315317. All data supporting our findings are included in the manuscript; however, additional data of this study may be provided by the corresponding author upon request. ACM, JCRR, and JUC had full access to all the data in the study and takes responsibility for the decision to submit this work for publication. ACM, JCRR, CEG, and JUC designed the study, and ACM, JCRR, JVB, and CCS participated in data analysis and interpretation, manuscript drafting, and critical revision. DVM, CCS, and JVB performed field and laboratory work and contributed to data collection, data analysis and interpretation, and critical revision of the manuscript. All the authors read and approved the final version of the manuscript to be published. All authors declare no conflict of interest. The Committee on Animal Experimentation of the Universidad de Caldas, Manizales, Colombia, approved this study.

\section{REFERENCES}

Barkema, H. W., Y. H. Schukken, T. J. G. M. Lam, D. T. Galligan, M. L. Beiboer, and A. Brand. 1997. Estimation of interdependence among quarters of the bovine udder with subclinical mastitis and implications for analysis. J. Dairy Sci. 80:1592-1599. https://doi .org/10.3168/jds.S0022-0302(97)76089-2.

Barkema, H. W., M. G. von Keyserlingk, J. P. Kastelic, T. J. G. M Lam, C. Luby, J.-P. Roy, S. J. LeBlanc, G. P. Keefe, and D. F. Kelton. 2015. Invited review: Changes in the dairy industry affecting dairy cattle health and welfare. J. Dairy Sci. 98:7426-7445. https: //doi.org/10.3168/jds.2015-9377.

Barth, K. 2000. Basic investigations to evaluate a highly sensitive infrared- thermograph-technique to detect udder inflammation in cows. Milchwissenschaft 55:607-609.

Berry, R. J., A. D. Kennedy, S. L. Scott, B. L. Kyle, and A. L. Schaefer. 2003. Daily variation in the udder surface temperature of dairy cows measured by infrared thermography: Potential for mastitis detection. Can. J. Anim. Sci. 83:687-693. https://doi.org/10.4141/ A03-012.

Cicchetti, D. V., and A. R. Feinstein. 1990. High agreement but low kappa: II. Resolving the paradoxes. J. Clin. Epidemiol. 43:551558. https://doi.org/10.1016/0895-4356(90)90159-M.

Colak, A., B. Polat, Z. Okumus, M. Kaya, L. E. Yanmaz, and A. Hayirli. 2008. Short communication: Early detection of mastitis using infrared thermography in dairy cows. J. Dairy Sci. 91:4244-4248. https://doi.org/10.3168/jds.2008-1258.

Condas, L. A. Z., J. De Buck, D. B. Nobrega, D. A. Carson, J.-P. Roy, G. P. Keefe, T. J. DeVries, J. R. Middleton, S. Dufour, and H. W. Barkema. 2017. Distribution of non-aureus staphylococci species in udder quarters with low and high somatic cell count, and clinical mastitis. J. Dairy Sci. 100:5613-5627. https://doi.org/10.3168/jds .2016-12479.

Dash, S., A. K. Chakravarty, A. Singh, A. Upadhyay, M. Singh, and S. Yousuf. 2016. Effect of heat stress on reproductive performances of dairy cattle and buffaloes: A review. Vet. World 9:235-244. https: //doi.org/10.14202/vetworld.2016.235-244. 
DeLong, E. R., D. M. DeLong, and D. L. Clarke-Pearson. 1988. Comparing the areas under two or more correlated receiver operating characteristic curves: A nonparametric approach. Biometrics 44:837-845. https://doi.org/10.2307/2531595.

Dingwell, R. T., K. E. Leslie, Y. H. Schukken, J. M. Sargeant, and L. L. Timms. 2003. Evaluation of the California Mastitis Test to detect an intramammary infection with a major pathogen in early lactation dairy cows. Can. Vet. J. 44:413-415.

Djabri, B., N. Bareille, F. Beaudeau, and H. Seegers. 2002. Quarter milk somatic cell count in infected dairy cows: A meta-analysis. Vet. Res. 33:335-357. https://doi.org/10.1051/vetres:2002021.

Dohoo, I. R., W. Martin, and H. Stryhn. 2009. Veterinary Epidemiologic Research. 2nd ed. VER Inc.

Dohoo, I. R., J. Smith, S. Andersen, D. F. Kelton, and S. Godden. 2011. Diagnosing intramammary infections: Evaluation of definitions based on a single milk sample. J. Dairy Sci. 94:250-261. https://doi.org/10.3168/jds.2010-3559.

Eddy, A. L., L. M. Van Hoogmoed, and J. R. Snyder. 2001. The role of thermography in the management of equine lameness. Vet. J. 162:172-181. https://doi.org/10.1053/tvjl.2001.0618.

Fluss, R., D. Faraggi, and B. Reiser. 2005. Estimation of the Youden Index and its associated cutoff point. Biom. J. 47:458-472. https:/ /doi.org/10.1002/bimj.200410135.

Gonçalves, J. L., C. Kamphuis, C. M. M. R. Martins, J. R. Barreiro, T. Tomazi, A. H. Gameiro, H. Hogeveen, and M. V. dos Santos. 2018. Bovine subclinical mastitis reduces milk yield and economic return. Livest. Sci. 210:25-32. https://doi.org/10.1016/ j.livsci.2018.01.016.

Grimes, D. A., and K. F. Schulz. 2005. Refining clinical diagnosis with likelihood ratios. Lancet 365:1500-1505. https://doi.org/10.1016/ S0140-6736(05)66422-7.

Hamann, J. 2003. Definition of the physiological cell count threshold based on changes in milk composition. Pages 9-12 in Mastitis Newsletter No 25. International Dairy Federation.

Harmon, R. J. 1994. Physiology of mastitis and factors affecting somatic cell counts. J. Dairy Sci. 77:2103-2112. https://doi.org/10 .3168/jds.S0022-0302(94)77153-8.

Hayden, S. R., and M. D. Brown. 1999. Likelihood ratio: A powerful tool for incorporating the results of a diagnostic test into clinical decision making. Ann. Emerg. Med. 33:575-580. https://doi.org/ 10.1016/S0196-0644(99)70346-X.

Hogan, J., R. Gonzalez, R. Harmon, S. Nickerson, S. Oliver, J. Pankey, and K. Smith. 1999. Laboratory Handbook on Bovine Mastitis. 2nd ed. National Mastitis Council.

Hovinen, M., J. Siivonen, S. Taponen, L. Hänninen, M. Pastell, A. M. Aisla, and S. Pyörälä. 2008. Detection of clinical mastitis with the help of a thermal camera. J. Dairy Sci. 91:4592-4598. https://doi .org/10.3168/jds.2008-1218.

Jashari, R., S. Piepers, and S. De Vliegher. 2016. Evaluation of the composite milk somatic cell count as a predictor of intramammary infection in dairy cattle. J. Dairy Sci. 99:9271-9286. https://doi .org/10.3168/jds.2015-10753.

Jayarao, B. M., S. R. Pillai, A. A. Sawant, D. R. Wolfgang, and N. V. Hegde. 2004. Guidelines for monitoring bulk tank milk somatic cell and bacterial counts. J. Dairy Sci. 87:3561-3573. https://doi.org/ 10.3168/jds.S0022-0302(04)73493-1.

Kandeel, S. A., A. A. Megahed, M. H. Ebeid, and P. D. Constable. 2019. Evaluation of 3 esterase tests for the diagnosis of subclinical mastitis at dry-off and freshening in dairy cattle. J. Dairy Sci. 102:1402-1416. https://doi.org/10.3168/jds.2017-14345.

Landis, J. R., and G. G. Koch. 1977. The measurement of observer agreement for categorical data. Biometrics 33:159-174. https://doi .org $/ 10.2307 / 2529310$.

Lowe, G., A. Schaefer, J. Waas, M. Wilson, M. Sutherland, and M. Stewart. 2016. Brief communication: The use of infrared thermography and feeding behaviour for early disease detection in New Zealand dairy calves. Proc. N.Z. Soc. Anim. Prod. 76:177-179.

Mader, T. L., M. S. Davis, and T. Brown-Brandl. 2006. Environmental factors influencing heat stress in feedlot cattle. J. Anim. Sci. 84:712-719. https://doi.org/10.2527/2006.843712x.
Metzner, M., C. Sauter-Louis, A. Seemueller, W. Petzl, and W. Klee. 2014. Infrared thermography of the udder surface of dairy cattle: Characteristics, methods, and correlation with rectal temperature. Vet. J. 199:57-62. https://doi.org/10.1016/j.tvjl.2013.10.030.

Metzner, M., C. Sauter-Louis, A. Seemueller, W. Petzl, and H. Zerbe. 2015. Infrared thermography of the udder after experimentally induced Escherichia coli mastitis in cows. Vet. J. 204:360-362. https: //doi.org/10.1016/j.tvj1.2015.04.013.

Moreira, L. H., J. C. P. de Souza, C. J. de Lima, M. A. C. Salgado, A. B. Fernandes, D. I. K. Andreani, A. B. Villaverde, and R. A. Zângaro. 2018. Use of photodynamic therapy in the treatment of bovine subclinical mastitis. Photodiagnosis Photodyn. Ther. 21:246-251. https://doi.org/10.1016/j.pdpdt.2017.12.009.

Moroni, P., D. V. Nydam, P. A. Ospina, J. C. Scillieri-Smith, P. D. Virkler, R. D. Watters, F. L. Welcome, M. J. Zurakowski, N. G. Ducharme, and A. E. Yeager. 2018. Diseases of the Teats and Udder. 3rd ed. Elsevier Inc.

Nakagawa, Y., N. A. Nassary, K. Fukuyama, and I. Kobayashi. 2016. Measurement of udder surface temperature in cows using infrared thermometer. Pages 429-434 in Genetic and Evolutionary Computing. Advances in Intelligent Systems and Computing, Vol. 387. T. Zin, J. W. Lin, J. S. Pan, P. Tin, and M. Yokota, ed. Springer. https://doi.org/10.1007/978-3-319-23204-1_43.

Nasr, M. A. F., and M. S. El-Tarabany. 2017. Impact of three THI levels on somatic cell count, milk yield and composition of multiparous Holstein cows in a subtropical region. J. Therm. Biol. 64:73-77. https://doi.org/10.1016/j.jtherbio.2017.01.004.

Nikkhah, A., J. C. Plaizier, M. S. Einarson, R. J. Berry, S. L. Scott, and A. D. Kennedy. 2005. Short communication: Infrared thermography and visual examination of hooves of dairy cows in two stages of lactation. J. Dairy Sci. 88:2749-2753. https://doi.org/10 .3168/jds.S0022-0302(05)72954-4.

Pampariene, I., V. Veikutis, V. Oberauskas, J. Zymantiene, R. Zelvyte, A. Stankevicius, D. Marciulionyte, and P. Palevicius. 2016. Thermography based inflammation monitoring of udder state in dairy cows: Sensitivity and diagnostic priorities comparing with routine California Mastitis Test. J. Vibroengieneering 18:511-521.

Peng, D., S. Chen, G. Li, J. Chen, J. Wang, and X. Gu. 2019. Infrared thermography measured body surface temperature and its relationship with rectal temperature in dairy cows under different temperature-humidity indexes. Int. J. Biometeorol. 63:327-336. https://doi.org/10.1007/s00484-018-01666-x.

Poikalainen, V., J. Praks, I. Veermäe, and E. Kokin. 2012. Infrared temperature patterns of cow's body as an indicator for health control at precision cattle farming. Agron. Res. (Tartu) 10:187-194.

Polat, B., A. Colak, M. Cengiz, L. E. Yanmaz, H. Oral, A. Bastan, S. Kaya, and A. Hayirli. 2010. Sensitivity and specificity of infrared thermography in detection of subclinical mastitis in dairy cows. J. Dairy Sci. 93:3525-3532. https://doi.org/10.3168/jds.2009-2807.

Porcionato, M. A. D. F., W. V. B. Soares, C. B. M. Dos Reis, C. S. Cortinhas, L. Mestieri, and M. V. Dos Santos. 2010. Milk flow, teat morphology and subclinical mastitis prevalence in Gir cows. Pesqui. Agropecu. Bras. 45:1507-1512. https://doi.org/10.1590/ S0100-204X2010001200023.

Porcionato, M. A. F., T. F. Canata, C. E. L. D. E. Oliveira, and M. Veiga dos Santos. 2009. Termografia do úbere de vacas Gir para detecção de mastite subclínica [Udder thermography of Gyr cows for subclinical mastitis detection]. Rev. Bras. Eng. Biossistemas 3:251. https://doi.org/10.18011/bioeng2009v3n3p251-257.

Pyörälä, S. 2003. Indicators of inflammation in the diagnosis of mastitis. Vet. Res. 34:565-578. https://doi.org/10.1051/vetres:2003026.

Ramírez, N., G. Gaviria, O. Arroyave, B. Sierra, and J. Benjumea. 2001. Prevalencia de mastitis en vacas lecheras lactantes en el municipio de San Pedro de los Milagros, Antioquia. Rev. Colomb. Cienc. Pecu. 14:76-87.

Ramírez, N. F., G. Keefe, I. Dohoo, J. Sánchez, O. Arroyave, J. Cerón, M. Jaramillo, and L. G. Palacio. 2014. Herd- and cow-level risk factors associated with subclinical mastitis in dairy farms from the High Plains of the northern Antioquia, Colombia. J. Dairy Sci. 97:4141-4150. https://doi.org/10.3168/jds.2013-6815. 
Riffon, R., K. Sayasith, H. Khalil, P. Dubreuil, M. Drolet, and J. Lagace. 2001. Development of a rapid and sensitive test for identification of major pathogens in bovine mastitis by PCR. J. Clin. Microbiol. 39:2584-2589. https://doi.org/10.1128/JCM.39.7.2584 $-2589.2001$

Riggio, V., L. L. Pesce, S. Morreale, and B. Portolano. 2013. Receiver-operating characteristic curves for somatic cell scores and California Mastitis Test in Valle del Belice dairy sheep. Vet. J. 196:528-532. https://doi.org/10.1016/j.tvjl.2012.11.010.

Ruegg, P. L. 2017. A 100-Year Review: Mastitis detection, management, and prevention. J. Dairy Sci. 100:10381-10397. https://doi .org/10.3168/jds.2017-13023.

Sanford, C. J., G. P. Keefe, J. Sanchez, R. T. Dingwell, H. W. Barkema, K. E. Leslie, and I. R. Dohoo. 2006. Test characteristics from latent-class models of the California Mastitis Test. Prev. Vet. Med. 77:96-108. https://doi.org/10.1016/j.prevetmed.2006.06.006.

Sathiyabarathi, M., S. Jeyakumar, A. Manimaran, G. Jayaprakash, H. A. Pushpadass, M. Sivaram, K. P. Ramesha, D. N. Das, M. A. Kataktalware, M. A. Prakash, and R. D. Kumar. 2016. Infrared thermography: A potential noninvasive tool to monitor udder health status in dairy cows. Vet. World 9:1075-1081. https://doi .org/10.14202/vetworld.2016.1075-1081.

Schaefer, A. L., N. Cook, S. V. Tessaro, D. Deregt, G. Desroches, P. L. Dubeski, A. K. W. Tong, and D. L. Godson. 2004. Early detection and prediction of infection using infrared thermography. Can. J. Anim. Sci. 84:73-80. https://doi.org/10.4141/A02-104.

Schukken, Y. H., D. J. Wilson, F. Welcome, L. Garrison-Tikofsky, and R. N. Gonzalez. 2003. Monitoring udder health and milk quality using somatic cell counts. Vet. Res. 34:579-596. https://doi.org/10 1051/vetres:2003028

Silva, R. A. B., H. Pandorfi, G. Luiz Pontes de Almeida, A. Antônio de Assunção Montenegro, and M. V. da Silva. 2019. Spatial dependence of udder surface temperature variation in dairy cows with healthy status and mastitis. Rev. Bras. Saúde Prod. Anim. 20:e01102019. https://doi.org/10.1590/s1519-99402001102019.

Stewart, M., J. R. Webster, G. A. Verkerk, A. L. Schaefer, J. J. Colyn, and K. J. Stafford. 2007. Non-invasive measurement of stress in dairy cows using infrared thermography. Physiol. Behav. 92:520 525. https://doi.org/10.1016/j.physbeh.2007.04.034.

Stewart, M., M. T. Wilson, A. L. Schaefer, F. Huddart, and M. A. Sutherland. 2017. The use of infrared thermography and accelerometers for remote monitoring of dairy cow health and welfare. J. Dairy Sci. 100:3893-3901. https://doi.org/10.3168/jds.2016-12055.

Stokes, J. E., K. A. Leach, D. C. J. Main, and H. R. Whay. 2012. An investigation into the use of infrared thermography (IRT) as a rapid diagnostic tool for foot lesions in dairy cattle. Vet. J. 193:674-678. https://doi.org/10.1016/j.tvjl.2012.06.052.

Talukder, S., K. L. Kerrisk, L. Ingenhoff, P. C. Thomson, S. C. Garcia, and P. Celi. 2014. Infrared technology for estrus detection and as a predictor of time of ovulation in dairy cows in a pasture-based system. Theriogenology 81:925-935. https://doi.org/10.1016/j .theriogenology.2014.01.009.

Testo SE and Co. 2017. Thermography Pocket Guide: Theory-Practice - Tips, and Tricks. 1st ed. Testo SE and Co.

Thompson, W. D., and S. D. Walter. 1988. A reappraisal of the kappa coefficient. J. Clin. Epidemiol. 41:949-958. https://doi.org/10 .1016/0895-4356(88)90031-5.

Thorberg, B. M., M. L. Danielsson-Tham, U. Emanuelson, and K. Persson Waller. 2009. Bovine subclinical mastitis caused by different types of coagulase-negative staphylococci. J. Dairy Sci. 92:4962-4970. https://doi.org/10.3168/jds.2009-2184.

Torres, A. H., P. J. Rajala-Schultz, and F. J. DeGraves. 2009. Diagnosis of intramammary infections at dry-off based on sampling strategy, epidemiology of pathogens, and agreement beyond chance. J. Vet. Diagn. Invest. 21:427-436. https://doi.org/10.1177/ 104063870902100403

Usamentiaga, R., P. Venegas, J. Guerediaga, L. Vega, J. Molleda, and F. Bulnes. 2014. Infrared thermography for temperature measurement and non-destructive testing. Sensors (Basel) 14:12305-12348. https://doi.org/10.3390/s140712305.

Velasco-Bolaños, J., L. M. Lasso-Rojas, and A. Ceballos-Márquez. 2019. Frequency of mammary pathogens in raw milk samples sent to the Laboratorio de Calidad de Leche y Epidemiología Veterinaria of Universidad de Caldas. Rev. Colomb. Cienc. Pecu. 32(Suppl.):168.

Viguier, C., S. Arora, N. Gilmartin, K. Welbeck, and R. O'Kennedy. 2009. Mastitis detection: Current trends and future perspectives. Trends Biotechnol. 27:486-493. https://doi.org/10.1016/j.tibtech 2009.05.004.

Ying, G.S., M.G. Maguire, R.J. Glynn, and B. Rosner. 2020. Calculating sensitivity, specificity, and predictive values for correlated eye data. Investig. Ophthalmol. Vis. Sci. 61:29. https://doi.org/10 $.1167 /$ iovs.61.11.29

Zaninelli, M., V. Redaelli, F. Luzi, V. Bronzo, M. Mitchell, V. Dell'Orto, V. Bontempo, D. Cattaneo, and G. Savoini. 2018. First evaluation of infrared thermography as a tool for the monitoring of udder health status in farms of dairy cows. Sensors (Basel) 18:862. https://doi.org/10.3390/s18030862. 